\title{
Pheromone responses of Ostrinia nubilalis (Hübner) from north of its range in Europe
}

\author{
Marianna I. Zhukovskaya ${ }^{1, *}$, Oksana G. Selitskaya ${ }^{2}$, Anna V. Shchenikova ${ }^{2}$, Andrey \\ $N$. Frolov ${ }^{2}$ \\ ${ }^{1}$ Sechenov Institute of Evolutionary Physiology and Biochemistry, Russian Academy of Sciences, \\ Lab. Evolution of Sensory Systems, 194223 St. Petersburg, Russia \\ ${ }^{2}$ All-Russian Institute of Plant Protection,Lab. Agricultural Entomology St. 196608, \\ Pushkin,Petersburg, Russia
}

\begin{abstract}
The European corn borer (ECB), Ostrinia nubilalis Hbn. (Lepidoptera: Crambidae) has recently become very harmful to maize in the North of its range in Europe, primarily in Belarus. Conventional pheromone-trapping methods however show very low effectiveness. Our electrophysiological study did not reveal any impairment in peripheral sensitivity, but flight-tunnel responses were low. The reason for such discrepancy could lie in breeding of the $\mathrm{Z}$ race of moth coming with maize from south with local populations of the pest.
\end{abstract}

\section{Introduction}

European corn borer (ECB), Ostrinia nubilalis Hbn. (Lepidoptera: Crambidae), is a major pest of maize, Zea mays worldwide. Successful selection of maize cultivars, improvements in agronomic practices and global climate change have markedly shifted the growing areas of maize towards temperate latitudes [1]. Several years later, the ECB begun to damage the crop to the north of $50^{\circ}$ Northern latitude (2). The species is divided into two pheromone races defined by their major sex pheromone stereoisomer component, Z (cis) or E (trans) 11-tetradecenyl acetate that they use for mate finding [3]. Both races are known to be generalist feeders, though in Europe the E-pheromone race tends to have a stronger association with nonmaize hosts whereas Z-pheromone race feeds mostly on maize. In North America ECB races are associated with voltinism, namely, bivoltine $\mathrm{E}$ race and monovoltine $\mathrm{Z}$ race, although it is not always true $[4,5]$, both of them are found on maize. Situation in Europe appears more complex, since together with two pheromone strains of ECB also the parent species, Ostrinia scapulalis, which employs the same pheromone system, is present $[6,7]$. The possibility of a host shifts, humanmediated dispersal and hybridization between Ostrinia species are also complicating the situation [8]. Recent data revealed ineffectiveness of pheromone traps for ECB in the northern area of maize growing [9]. Since the behavioral responses of male moth to pheromone stimuli are determined by olfactory receptor cells housed in antennal trichoid sensilla [10], the aim of the study was evaluation of peripheral sensitivity to pheromone

\footnotetext{
* Corresponding author: mzhukovskaya@yahoo.com
} 
components by means of electroantennogramm (EAG) and behavioral wind tunnel responses of the $O$. nubilalis males originating from Gomel region.

\section{Materials and Methods}

\subsection{Insects}

Diapausing larvae $O$. nubilalis were collected from stalks of maize plants in the corn field near Gomel, Belarus, in the fall of 2016 and 2018 . Larvae were kept at $5^{\circ} \mathrm{C}$ for diapause completion. Insects were reactivated in the spring of the next year at $25 \pm 2{ }^{\circ} \mathrm{C}$ under a $16 \mathrm{~h} / 8 \mathrm{~h}$ light/dark cycle. Virgin males from 3 to 5 days after imaginal eclosion were used in experiments.

\subsection{Pheromone stimuli}

(Z)-11-tetradecenyl acetate and (E)-11-tetradecenyl acetate (Shchelkovo Agrokhim, Russia) were dissolved in hexane to prepare the pheromone blends $\mathrm{E}$ (99:1 E to $\mathrm{Z}$ isomers), Z (3:97 E:Z) and EZ (65:35 E:Z) as a series of 10-fold dilutions in hexane.

\subsection{Electrophysiology}

Electroantennograms (EAGs) were recorded from isolated antennae as described earlier [11]. The antenna was cut near the base and the tip and fixed in a holder. Proximal and distal ends of the antenna contacted with ground and recording $\mathrm{Ag} / \mathrm{AgCl}$ electrodes respectively trough $1 \mathrm{M}$ solution of $\mathrm{NaCl}$. Resistance of the preparation was measured by a YF 3110 multimeter. Each preparation was tested with $10^{-7}, 10^{-6}$ and $10^{-5} \mathrm{mg}$ of each blend per dispenser. Each blend was tested starting from low to high dose; the order of blend was random. Stimulus duration was $1 \mathrm{c}$. Recorded in text files EAGs were transferred to MS Excel and. Records were smoothed by moving average method with window length of 5 points. EAG amplitude was calculated as a difference between the level of the signal before odor application and minimal value during stimulation. 26 antennae from 21 moths were used.

\subsection{Wind-tunnel experiments}

Airstream 0.2-0.3 m/c was blown along the plexiglass tube with diameter $400 \mathrm{~mm}$. Dosage of stimuli was the same as described above for electrophysiology. Experiments were carried out during the dark period of light regime under 10 lux infrared lite, ambient temperature $21-23^{\circ} \mathrm{C}$ and relative humidity of $75-80 \%$. Platform to release insects was placed $800 \mathrm{~mm}$ downwind from odor dispenser. ECB moth inside the glass Petri dish was put into releasing platform 5 min before the trail. The dish was open at the same time when the dispenser was introduced into the tunnel. Taking the flight was chosen as most robust reaction to stimuli. Proportion of males taking flight and latent period of the reaction were taken for the statistical evaluations. 248 insects were tested. 


\section{Results and Discussion}

\subsection{Electrophysiology}

EAG responses to $Z$ blend had shown the highest values and clear dose-response relationship (Fig. 1). One-way ANOVA applied to the 3 dose of $Z$ blend revealed significant difference $(\mathrm{p}<0.0001)$. Responses to $\mathrm{E}$ and $\mathrm{ZE}$ blends were also dosedependent $(p<0.001)$. It is interesting to note, that responses to high doses of $10-5 \mathrm{mg}$ were significantly higher for $Z$ blend, then for $E$ blend (Student's t-test, $\mathrm{p}<0.05$ ). Responses to the extract of pheromone glands of 3 females were similar with responses to low doses for all blends.

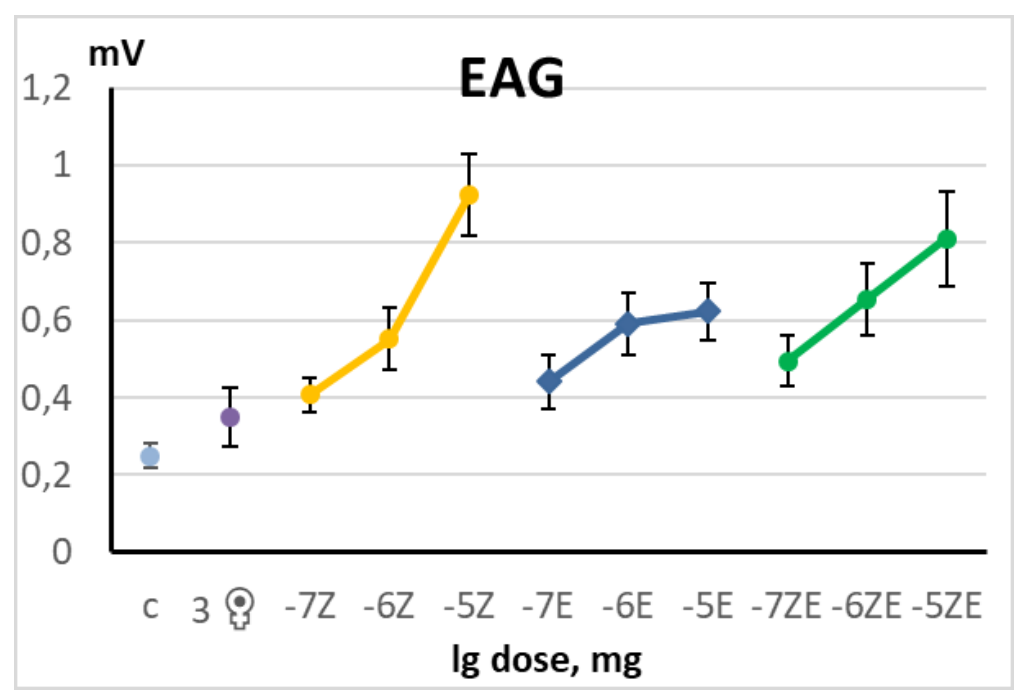

Fig.1. EAG amplitude $(\mathrm{mV})$ in response to control (10 $\mu \mathrm{l}$ of hexane, evaporated), female gland extract ( 3 + $)$, blends of $Z$ race, $E$ race and interracial hybrids $Z E$.

EAG amplitude was comparable with reported earlier for (Z)-11-tetradecenyl acetate and (E)-11-tetradecenyl acetate presented to males of both races and hybrids of ECB [12]. Thus, EAG testing did not show any substantial impairment in antennal sensitivity of the tested ECB population.

\subsection{Wind tunnel experiments}

Male moths showed all stages of pheromone response, but "taking flight" has been chosen as the most robust behavior. In response to pheromone gland extract from 3 virgin females the majority of insects (Fig. 2) have been taking flight. None of the blends in any of used dose showed a similar level of attractivity. Dose-effect relationships were not statistically significant. 


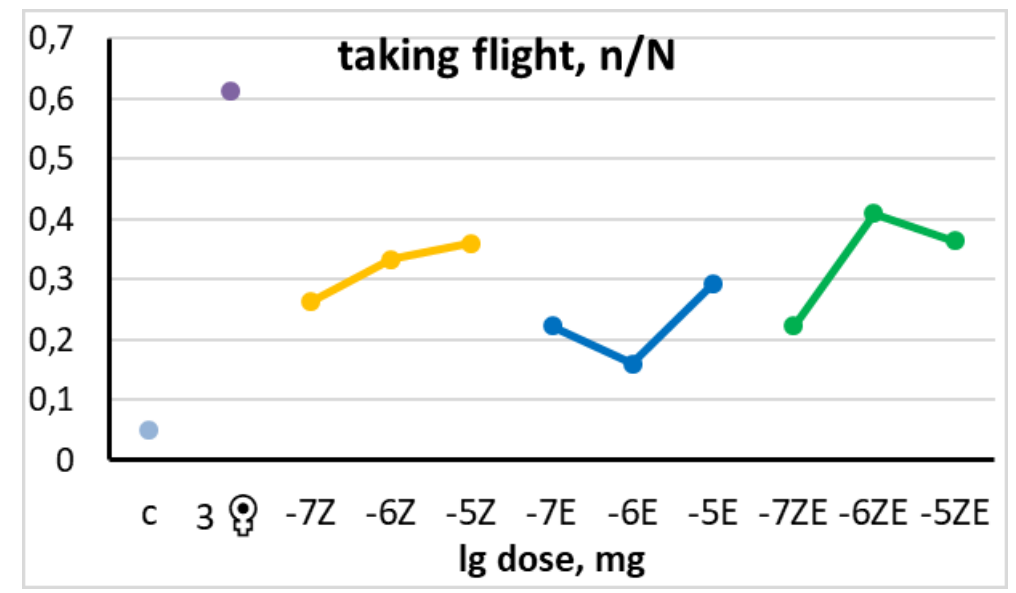

Fig. 2. Proportion of males, taking flight in response to control ( $10 \mu 1$ of hexane, evaporated), female gland extract ( 3 + ), blends of $Z$ race, $E$ race and interracial hybrids $Z E$.

Latent period between stimulus application and taking flight (Fig. 3) was shorter for the natural pheromone stimulus (female gland extract) and high doses of blends of $\mathrm{Z}$ and $\mathrm{E}$ races. Only one out of 20 control animals took flight after $8 \mathrm{c}$ delay. Dose-effect relationships were weak and did not show statistical significance (one-way ANOVA, $\mathrm{p}>0.05)$.

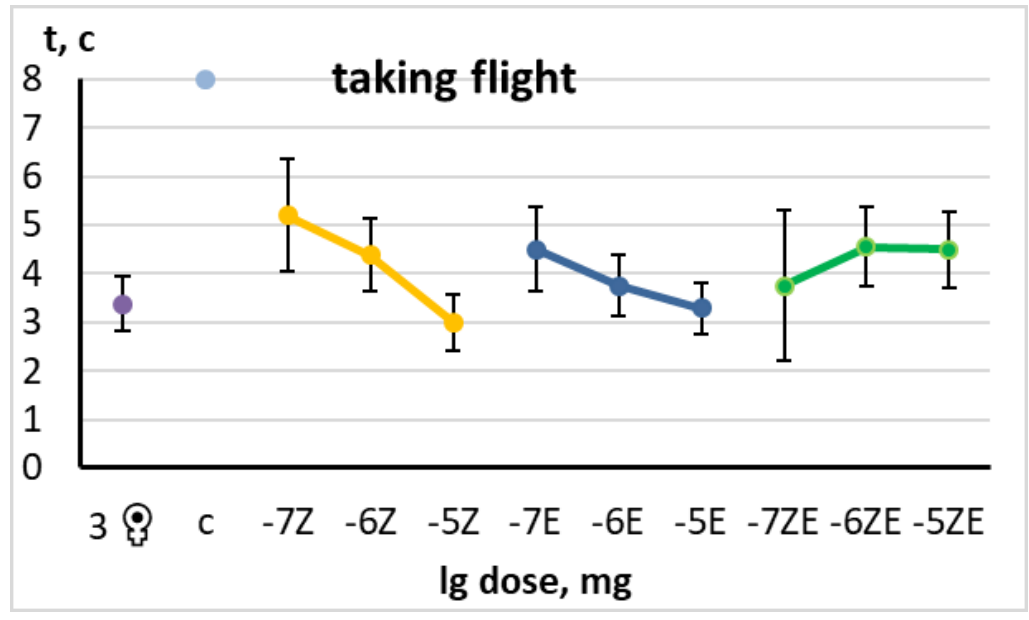

Fig. 3. Latent period for males, taking flight in response to control (10 $\mu 1$ of hexane, evaporated), female gland extract ( 3 +), blends of $Z$ race, $E$ race and interracial hybrids $Z E$.

The data obtained in wind-tunnel experiments demonstrate, that synthetic blends were about twofold less effective in eliciting flight responses of male moth as compared to the pheromone gland extract. 


\section{Conclusion}

Taking together electrophysiological and behavioral data, it becomes clear that low attractivity of all blends is not due to low antennal sensitivity. One can suggest, that the Gomel population is of mixed race, since the rate of responding males was $20-40 \%$ of tested males for each blend. It cannot be excluded that arriving with maize planting $\mathrm{Z}$ race partially interbread with local E race feeding on local weeds.Another plausible explanation of decreased behavioral response is longer maturation period, so the maximal responsibility is shifted to older males.

Supported by RFBR grant № 19-016-00128

\section{References}

1. J. L. Hatfield, C. Dold., Climate Change Impacts on Corn Phenology and Productivity, Corn - Production and Human Health in Changing Climate, Amanullah and Shah Fahad, IntechOpen (2018) http://doi.org/10.5772/intechopen.76933

2. L. I. Trepashko, A. V. Bykovskaya, Zaschita i karantin rastenii 7, 38-41 (2015) https://elibrary.ru/item.asp?id=23688477

3. T. J. Glover, X.-H.Tang, W. L.Roelofs, J. Chem. Ecol.. 13(1), 143-151 (1987) http://doi.org/10.1007/BF01020358

4. Jr. C.E. Linn, M.S. Young, M. Gendle, T.J. Glover, W.L. Roelofs, Physiol. Entomol. 22(3), 212-223 (1997).

5. E. B. Dopman, P. S. Robbins, A. Seaman, Evolution: Internat. J. Org. Evol. 64(4), 881-902. (2010)

6. A. N. Frolov, D. Bourguet, S.Ponsard, Biol. J. Linn. Soc. Lond. 91(1), 49-72. (2007) https://doi.org/10.1111/j.1095-8312.2007.00779.x

7. A. N. Frolov, P. Audiot, D. Bourguet, A.O.Kononchuk, J.M. Malysh, S.Ponsard, R. Streiff, Y.S. Tokarev. Heredity 108(2), 147-156 (2012).

8. M. Piwczyński, M. Pabijan, A. Grzywacz, W. Glinkowski, P. Bereś, J. Buszko, Bull. Entomol. Res. 106(4), 512-521 http://doi.org/10.1017/S0007485316000195

9. A.N. Frolov, T.A. Ryabchinskaya T.A. Plant Protection News [Vestnik Zashchity Rasteniy] 1(95), 5-11 (2018) http://doi.org/10.31993/2308-64592018-1(95)-5-11

10. B. S. Hansson, E. Hallberg, C. Lofstedt, R. A. Steinbrecht, Tissue Cell. 26, 503512 (1994) http://doi.org/10.1016/0040-8166(94)90003-5

11. M. I. Zhukovskaya, O.G. Selitskaya, A.V. Shchenikova, I.V. Grushevaya, Y.M. Malysh, M.N. Berim, A.N. Frolov, L.I. Trepashko, J. Evol. Biochem. Physiol. 53, 346-348 (2017)

12. H. W. Fescemyer, F. E. Hanson, J. Chem. Ecol. 16(3), 773-790. (1990) https://link.springer.com/article/10.1007/BF01016488 